\title{
E-FILING PADA KANTOR PELAYANAN PAJAK PRATAMA KOTA KEDIRI
}

\author{
Mar'atus Solikah \\ Universitas Nusantara PGRI Kediri \\ Email : solikahkediri@gmail.com \\ Dian Kusumaningtyas \\ Universitas Nusantara PGRI Kediri \\ Email : Diankusumaningtyas14@gmail.com
}

\begin{abstract}
The background of this research is based on the e-filing system that came into force in order to facilitate the taxpayers in reporting the Annual Tax Return so that it could reduce the non-compliance of tax reporting. However, for its implementation, it needs accurate and clear information about the clear procedures and procedures on the use of e-filing so as to achieve taxpayer compliance in the annual SPT reporting on the Directorate General of Tax. The purpose of this research is to find out how the implementation of e-filing based on its dimension, knowing Characteristics of reporting compliance, and e-filing relationships against taxpayer reporting compliance. The population in this study are all personal tax payers in Kediri, the sampling technique sampling sampling with a total of 200 samples. Data collection using questionnaire. Dimensions in e-filing variables in this study are System Quality, Quality of Information, Usage, User Satisfaction. Data analysis techniques using SmartPLS. The results of research Overall taxpayers are satisfied with the existence of e-filing system while for the characteristics of compliance reporting Annual Notification by using $e$ filing system able to help taxpayers avoid the fines delayed reporting SPT and there is significant influence between e-filing with compliance reporting Annual Notice
\end{abstract}

Keywords: e-filing, taxes

\begin{abstract}
Abstrak
Latar belakang penelitian ini didasarkan pada sistem e-filing yang mulai diberlakukan dengan tujuan untuk mempermudah para wajib pajak dalam melaporkan SPT Tahunan sehingga mamapu mengurangi adanya ketidakpatuhan pelaporan pajak. Namun untuk implementasinya dibutuhkan informasi yang akurat dan jelas mengenai tata cara serta prosedur yang jelas tentang penggunaan e-filing sehingga tercapai kepatuhan wajib pajak dalam pelaporan SPT tahunan pada Direktorat Jendral Pajak.Tujuan dalam penelitian ini untuk mengetahui bagaimana implementasi $e$-filing berdasarkan dimensinya, mengetahui karakteristik kepatuhan pelaporan, dan hubungan $e$-filing terhadap kepatuhan pelaporan wajib pajak. Populasi dalam penelitian ini adalah seluruh wajib pajak pribadi di Kota Kediri, penentuan sampelnya teknik judgement sampling dengan total 200 sampel. Pengambilan data dengan menggunakan kuisioner. Dimensi dalam variabel $e$-filing dalam penelitian ini adalah Kualitas sistem, Kualitas informasi, Penggunaan, Kepuasan pemakai. Teknik analisa data menggunakan SmartPLS. Hasil penelitian Secara menyeluruh wajib pajak merasa puas dengan adanya sistem $e$-filing sedangkan untuk karakteristik kepatuhan pelaporan Surat Pemberitahuan
\end{abstract}


Tahunan dengan menggunakan sistem $e$-filing mampu membantu wajib pajak terhindar akan denda keterlambatan pelaporan SPT dan terdapat pengaruh yang signifikan antara $e$-filing dengan kepatuhan pelaporan Surat Pemberitahuan tahuna

Kata kunci: $e$-filing, pajak

\section{PENDAHULUAN}

Mengantisipasi perkembangan informasi dan teknologi tersebut, Direktorat Jendral Pajak berusaha untuk memenuhi aspirasi Wajib Pajak (WP) dengan mempermudah tata cara pelaporan Surat Pemberitahuan (SPT) baik itu SPT Masa maupun SPT Tahunan. Pembaharuan dalam sistem perpajakan yang dilakukan oleh DJP tersebut tidak lain adalah sebagai bagian dari reformasi perpajakan, khususnya administrasi perpajakan. Modernisasi pajak ini ditandai dengan penerapan teknologi informasi terkini dalam pelayanan perpajakan. Peningkatan pelayanan perpajakan ini terlihat dengan dikembangkannya administrasi perpajakan modern dan teknologi informasi di berbagai aspek kegiatan.

E-filing adalah layanan pengisian dan penyampaian Surat Pemberitahuan (SPT) secara elektronik kepada Direktorat Jendral Pajak, dengan memanfaatkan jalur komunikasi internet. Dengan menggunakan sistem ini, membuat para wajib pajak akan lebih mudah menunaikan kewajibannya dalam melakukan pelaporan tanpa harus mengantri dikantor pelayanan pajak sehingga dirasa lebih efektif dan efisien. Selain itu wajib pajak bisa mengirimkan data surat pemberitahuan (SPT) dimana saja dan kapan saja baik di dalam maupun luar negeri, tidak tergantung pada jam kantor dan dapat dilakukan saat hari libur (24 jam dalam 7 hari), kemudian data akan dikirim langsung ke database. Direktorat Jendral Pajak dengan fasilitas internet (on-line) yang disalurkan melalui satu atau beberapa Perusahaan Penyedia jasa.

Penggunaan $e$-filing juga mampu mengurangi beban proses administrasi laporan pajak menggunakan kertas (Dewi dan Ratih, 2009). Wiyono (2008) menyatakan e-filing sangat berperan dalam meminimalisasi ketidakakuratan Model Penerimaan Negara (MPN). E-filing adalah sebuah layanan pengiriman atau penyampaian SPT secara elektronik baik untuk orang pribadi maupun Badan (perusahaan, organisasi) ke Direktorat Jendral Pajak melalui sebuah ASP (Application Service Provider atau Penyedia Jasa Aplikasi) dengan memanfaatkan jalur komunikasi internet secara on-line dan real time, sehingga Wajib Pajak tidak perlu lagi melakukan pencetakan semua 
formulir laporan dan menunggu tanda terima secara manual. Dengan begitu, sistem $e$ filing ini dirasa lebih efektif dan efisien. Dewi dan Ratih (2009) mengatakan jika partisipasi Wajib Pajak dalam penggunaan e-filing masih rendah maka akan mengakibatkan return yang diterima Direktoral Jendral Pajak juga rendah. Hal ini akan merugikan Direktorat Jendral Pajak yang sudah mengeluarkan biaya yang sangat besar untuk menciptakan sistem Informasi yang lebih baik demi memberikan kemudahan dalam administrasi perpajakan. Sehingga diharapkan para wajib pajak lebih berhati-hati dan harus benar-benar mengerti mengenai bagaimana cara penggunaan sistem ini. Berdasarkan uraian diatas dapat disimpulkan bahwa perlu adanya informsi yang akurat dan jelas mengenai tata cara serta prosedur yang jelas tentang penggunaan $e$-filing sehingga tercapai kepatuhan wajib pajak dalam pelaporan SPT tahunan pada Direktorat Jendral Pajak.

\section{KAJIAN PUSTAKA}

\section{E-Filing}

Salah satu program yang sedang digalakkan oleh pihak DJP adalah fasilitas pelaporan pajak dengan menggunakan e-filing. Berdasarkan Keputusan Direktur Jenderal Pajak Nomor: KEP- 88/PJ./2004 tanggal 14 Mei 2004 jo KEP-05/PJ./2005 tanggal 12 Januari 2005 tentang Tata Cara Penyampaian Surat Pemberitahuan Secara Elektronik (e-filing) melalui Perusahaan Penyedia Jasa Aplikasi (ASP), e-filing adalah Surat Pemberitahuan Masa atau Tahunan yang berbentuk formulir elektronik dalam media komputer, dimana penyampaiannya dilakukan secara elektronik dalam bentuk data digital yang ditransfer atau disampaikan ke Direktorat Jenderal Pajak melalui Perusahaan Penyedia Jasa Aplikasi atau Application Service Provider (ASP) yang telah ditunjuk oleh Direktur Jenderal Pajak dengan proses secara online dan real time.

\section{Pengukuran Kualitas Sistem}

Pengukuran kualitas sistem berdasarkan Jogiyanto (2007) antara lain sebagai berikut terdapat kualitas sistem, kualitas informasi, pengguna informasi dan kepuasan pemakai

\section{Kepatuhan}

Kepatuhan didefinisikan sebagai suatu keadaan dimana Wajib Pajak memenuhi semua kewajiban dan melaksanakan hak perpajakannya (Nurmantu, 2003:148). 
Pengukuran Kepatuhan Berdasarkan Peraturan Menteri Keuangan Nomor 192/PMK.03/2007, Wajib Pajak termasuk dalam kategori Wajib Pajak patuh apabila memenuhi kriteria sebagai berikut:

a. Tepat waktu dalam menyampaikan surat pemberitahuan.

b. Tidak mempunyai tunggakan pajak untuk semua jenis pajak, kecuali telah memperoleh izin untuk mengangsur atau menunda pembayaran pajak.

c. Tidak pernah dijatuhi hukuman karena melakukan tindak pidana di bidang perpajakan dalam jangka waktu lima tahun terakhir.

d. Wajib Pajak yang laporan keuangannya tiga tahun terakhir diaudit oleh akuntan publik atau lembaga pengawas keuangan pemerintah dengan pendapat wajar tanpa pengecualian

\section{Kerangka Pikir}

\section{Gambar 1. Model kerangka pikir}

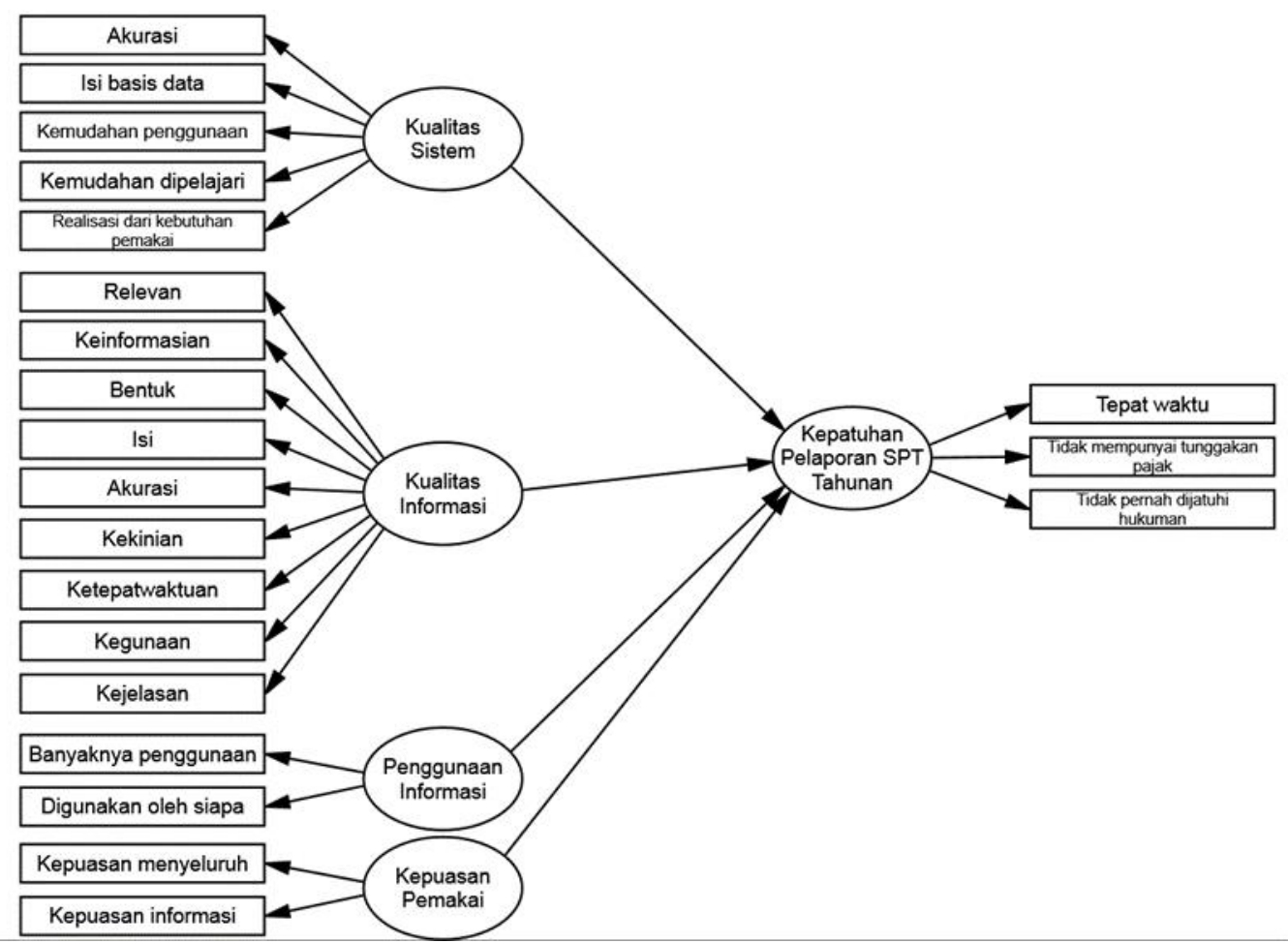

\section{Hipotesis}

$\mathrm{H}_{1}=$ Terdapat pengaruh signifikan antara kualitas sistem dengan kepatuhan pelaporan SPT tahunan 
$\mathrm{H}_{2}=$ Terdapat pengaruh signifikan antara kualitas informasi dengan kepatuhan pelaporan SPT tahunan

$\mathrm{H}_{3}=$ Terdapat pengaruh signifikan antara penggunaan informasi dengan kepatuhan pelaporan SPT tahunan

$\mathrm{H}_{4}=$ Terdapat pengaruh signifikan antara kepuasan pemakai dengan kepatuhan pelaporan SPT tahunan

\section{METODE PENELITIAN}

\section{Prosedur dan Teknik Penelitian}

Perbedaan penelitian ini dengan yang lain untuk penelitian widilestariningtyas dan utami (2015) dibedakan pada variabel yang ada pada $e$-filing dan kesadaran wajib pajak, sedangkan untuk penelitian ini lebih mengupang untuk sistem efilingnya yang berdasarkan sistem, informasi, pengguna dan kepuasan. Penelitian lainnya agustiningsih (2016) perbedaan pada variabelnya dimana penerapan e-filing, tingkat pemahaman dan kesadaran wajib pajak serta alat analisisnya menggunakan regresi linier berganda sedangkan untuk penelitian ini menggunakan smartPLS.

\section{Populasi dan Sampel}

Populasi dalam penelitian ini merupakan seluruh wajib pajak pribadi yang menggunakan fasilitas e-filing atau telah menggunakan e-filing di Kota Kediri. Untuk sampel menggunakan teknik judgement sampling merupakan teknik sampling dengan cara pengambilan sampel yang tidak dilakukan secara random tetapi berdasarkan keinginan peneliti (Marzuki, 2000 : 42). Metode pengambilan sampel dipilih untuk memudahkan pelaksanaan penelitian dengan alasan bahwa jumlah populasi yang diteliti tidak diketahui sehingga terdapat kebebasan untuk memilih sampel yang paling cepat dan mudah. Sehingga sampel ditentukan peneliti berjumlah 250 orang.

\section{Metode Pengumpulan Data, Variabel dan Alat analisis}

Pengumpulan data dengan menyebarkan kuesioner kepada responden baik melalui perantara maupun diberikan secara langsung kepada individu yang bersangkutan. Penyebaran kuesioner dilakukan dengan mendatangi satu persatu calon responden, mengecek apakah calon memenuhi persyaratan sebagai calon responden, lalu menanyakan kesediaannya untuk mengisi kuesioner. Penyebaran kuesioner ini dilakukan oleh peneliti dan dibantu oleh rekan peneliti. . 


\section{HASIL DAN PEMBAHASAN}

Kuisioner disebarkan sejumlah 250 namunter ada beberapa resonden yang tidak berkenan untuk mengisi.

\section{Tabel 1. Distribusi Kuisioner}

\begin{tabular}{|l|l|}
\hline Keterangan & Jumlah Kuisioner \\
\hline Jumlah kuisioner yang dikirim & 250 \\
- Kuisioner yang kembali & 200 \\
- Kuisioner yang tidak kembali & 20 \\
- Kuisioner yang tidak leyap/rusak & 30 \\
\hline Sampel akhir pengamatan & 200 \\
\hline
\end{tabular}

Sumber: Data kuisioner, 2017

\section{A. Pengertian $E$-filing}

Berdasarkan peraturan Direktur Jendral Pajak Nomor PER-06/PJ./2014 e-filing adalah suatu cara penyampaian SPT Tahunan secara elektronik yang dilakukan secara on-line dan realtime melalui internet pada website Direktorat Jendral Pajak (www.pajak.go.id atau http://efiling.pajak.go.id).

B. Tata Cara Penyampaian Surat Pemberitahuan Tahunan bagi Wajib Pajak

\section{Orang Pribadi}

Dokumen yang dibutuhkan untuk $e$-filing

1. Kartu NPWP atau surat keterangan terdaftar

2. Kartu identitas diri

3. Alamat email

4. Dokumen yang digunakan untuk mengisi SPT

Langkah - langkah yang dilakukan dalam proses $e$-filing

1. Mengajukan permohonan e-FIN

a. Datang langsung ke KPP terdaftar, e-FIN akan diberikan langsung kepada wajib pajak (1 hari kerja) dengan membawa persyaratan mengisi formulir, nama dan NPWP sesuai dengan master file WP, menunjukkan asli kartu identitas diri, surat kuasa atau identitas WP bila dikuasakan.

b. Secara on-line melalui www.pajak.go.id, e-FIN akan dikirim ke alamat wajib pajak sesuai yang terdaftar dibasis data Direktorat Jendral Pajak (3 hari kerja dan waktu pengiriman) dengan syarat mengisi formulir, nama dan NPWP sesuai dengan master file WP. 
2. Mendaftarkan sebagai wajib pajak e-filing di www.pajak.go.id paling lama 30 hari sejak diterbitkannya e-FIN.

Tata cara pendaftaran $e$-filing

a. Buka menu e-filing di website DJP

b. Masukkan NPWP dan e-FIN

c. Isikan data email, nomor hp dan password

d. Log-in aplikasi e-filing menggunakan email sebagai username dan password

3. Menyampaikan SPT melalui $e$-filing

a. Mengisi e-SPT pada aplikasi $e$-filing di www.pajak.go.id

b. Meminta kode verifikasi untuk pengiriman e-SPT, kode verifikasi akan dikirim melalui email atau SMS

c. Mengirim SPT secara on-line dengan mengisikan kode verifikasi

d. Notifikasi status e-SPT dan bukti penerimaan Elektronik akan diberikan kepada wajib pajak.

\section{Implementasi $E$-filing dalam Sistem Pelaporan Surat pemberitahuan Tahunan}

Penerapan layanan $e$-filing bertujuan untuk membuat prosedur penyampaian SPT yang lebih mudah, murah, cepat yang sesuai dengan ketentuan. Dengan adanya layanan e-filing diharapkan mampu mengurangi dampak antrian dan volume pekerjaan saat proses penerimaan SPT, mengurangi adanya volume berkas fisik dokumen perpajakan dan mampu mengurangi pertemuan secara langsung antara wajib pajak dengan petugas pajak.

Dalam pengukuran kesuksesan sistem berdasarkan Jogiyanto (2007), sistem e-filing akan dilihat dari beberapa dimensi yaitu kualitas sistemnya, kualitas informasi yang diberikan, penggunaan informasi serta kepuasaan pemakai. Berdasarkan kuisioner yang telah didistribusikan sehingga diperoleh frekuensi dari masing-masing dimensi antara lain sebagai berikut :

Tabel 2.Tabel Frekuensi Kualitas Sistem

\begin{tabular}{|c|c|c|c|c|c|c|}
\hline Item & STS & TS & N & S & SS & Rata-Rata \\
\hline $\mathrm{x} 1.1$ & 9 & 52 & 64 & 43 & 32 & 3,19 \\
\hline $\mathrm{x} 1.2$ & 0 & 42 & 73 & 80 & 5 & 3,24 \\
\hline $\mathrm{x} 1.3$ & 0 & 15 & 63 & 113 & 9 & 3,58 \\
\hline $\mathrm{x} 1.4$ & 0 & 44 & 19 & 63 & 74 & 3,84 \\
\hline $\mathrm{x} 1.5$ & 13 & 28 & 37 & 85 & 37 & 3,53 \\
\hline
\end{tabular}

Sumber: Output SPSS 
Berdasarkan tabel 4.2 di atas, diketahui bahwa kualitas sistem telah dipersepsikan baik oleh responden. Hal ini ditunjukkan dari sebagian besar jawaban responden setuju dan sangat setuju serta rata-rata yang lebih besar dari 3 tentang sistem E-filing detail dan akurat, isi basis data dalam E-filing sesuai dengan kebutuhan Wajib Pajak, sistem E-filing mudah penggunaannya, sistem E-filing mudah untuk dipelajari, dan sistem E-filing merupakan realisasi kebutuhan Wajib Pajak.

Tabel 3. Frekuensi Kualitas Informasi

\begin{tabular}{|l|c|c|c|c|c|c|}
\hline Item & STS & TS & N & S & SS & Rata-Rata \\
\hline X2.1 & 0 & 26 & 38 & 100 & 36 & 3,73 \\
\hline X2.2 & 6 & 37 & 82 & 63 & 12 & 3,19 \\
\hline X2.3 & 0 & 6 & 59 & 135 & 0 & 3,65 \\
\hline X2.4 & 0 & 19 & 21 & 140 & 20 & 3,81 \\
\hline X2.5 & 0 & 13 & 50 & 104 & 33 & 3,79 \\
\hline X2.6 & 0 & 1 & 26 & 109 & 64 & 4,18 \\
\hline X2.7 & 0 & 7 & 98 & 78 & 17 & 3,53 \\
\hline X2.8 & 0 & 25 & 75 & 87 & 13 & 3,44 \\
\hline X2.9 & 0 & 22 & 98 & 56 & 24 & 3,41 \\
\hline
\end{tabular}

Sumber: Output SPSS

Berdasarkan tabel 4.3 di atas, diketahui bahwa kualitas informasi telah dipersepsikan baik oleh responden. Hal ini ditunjukkan dari sebagian besar jawaban responden setuju dan sangat setuju serta rata-rata yang lebih besar dari 3 tentang sistem E-filing yang relevan, informatif, format informasi yang mudah dipahami, isi atau komponen dalam sistem E-filing memberikan informasi yang memadai, informasi yang diberikan E-filing akurat, sistem E-filing selalu memberikan informasi terbaru sesuai kebijakan Pemerintah, Informasi yang diberikan E-filing tepat waktu, Informasi yang diberikan E-filing berguna sesuai kebutuhan, sistem $E$ filing selalu memberikan informasi yang jelas.

Tabel 4. Frekuensi penggunaan informasi

\begin{tabular}{|c|c|c|c|c|c|c|}
\hline Item & STS & TS & N & S & SS & Rata-Rata \\
\hline X3.1 & 0 & 1 & 76 & 76 & 47 & 3,85 \\
\hline X3.2 & 0 & 15 & 108 & 66 & 11 & 3,73 \\
\hline
\end{tabular}

Sumber: Output SPSS

Berdasarkan tabel 4.4 di atas, diketahui bahwa penggunaan informasi telah dipersepsikan baik oleh responden. Hal ini ditunjukkan dari sebagian besar jawaban 
responden setuju dan sangat setuju serta rata-rata yang lebih besar dari 3 tentang banyaknya pengguna yang mengakses dalam waktu bersamaan tidak membuat sistem menjadi lambat dan pengguna sistem E-filing adalah wajib pajak yang akan melaporkan SPT nya.

Tabel 5. Frekuensi Kepuasan Pemakai

\begin{tabular}{|l|c|c|c|c|c|c|}
\hline Item & STS & TS & N & S & SS & Rata-Rata \\
\hline X4.1 & 1 & 2 & 83 & 85 & 29 & 3,70 \\
\hline 4.2 & 0 & 26 & 102 & 52 & 20 & 3,73 \\
\hline
\end{tabular}

Sumber: Output SPSS

Berdasarkan tabel 4.5 di atas, diketahui bahwa kepuasan pemakai telah dipersepsikan baik oleh responden. Hal ini ditunjukkan dari sebagian besar jawaban responden setuju dan sangat setuju serta rata-rata yang lebih besar dari 3 tentang Sistem E-filing secara keseluruhan memuaskan Wajib Pajak dan Informasi yang diberikan memuaskan sesuai dengan yang dibutuhkan Wajib Pajak.

\section{Karakteristik Kepatuhan Pelaporan Surat Pemberitahuan Tahunan}

Kepatuhan wajib pajak dalam memenuhi kewajibannya dalam SPT merupakan tulang punggung sistem selt assessment. Kepatuhan wajib pajak menurut Rahayu (2010:138) adalah suatu keadaan dimana wajib pajak memenuhi semua kewajiban perpajakan dan diharapkan mampu meningkatkan kepatuhan.

Tabel 6. Frekuensi Kepatuhan Pelaporan

\begin{tabular}{|c|c|c|c|c|c|c|}
\hline Item & STS & TS & N & S & SS & Rata-Rata \\
\hline $\mathrm{y} 1$ & 0 & 7 & 65 & 96 & 32 & 3,77 \\
\hline $\mathrm{y} 2$ & 0 & 7 & 23 & 112 & 58 & 4,11 \\
\hline $\mathrm{y} 3$ & 0 & 5 & 28 & 121 & 46 & 4,04 \\
\hline
\end{tabular}

Sumber: Output SPSS

Berdasarkan tabel 4.6 di atas, diketahui bahwa kepatuhan pelaporan telah dipersepsikan baik oleh responden. Hal ini ditunjukkan dari sebagian besar jawaban responden setuju dan sangat setuju serta rata-rata yang lebih besar dari 3,5 tentang sistem E-filing mampu membantu wajib pajak untuk melaporkan SPT tahunan tepat waktu, sistem E-filing mampu membantu para wajib pajak sehingga terhindar tunggakan pajak, dan dengan mengakses sistem E-filing mampu menghindarkan wajib pajak dari denda keterlambatan. 


\section{E. Pengaruh e-filing terhadap kepatuhan pelaporan Surat Pemberitahuan Tahunan}

Hasil pengujian hipotesis dengan menggunakan Partial Least Square (PLS), dengan menggunakan 2 tahap yaitu evaluasi model pengukuran (outer model) dan evaluasi terhadap model struktural (inner model).

\section{Outer Model}

a) Convergent Validity

Tabel 7. Nilai Outer Loading

\begin{tabular}{|c|c|c|c|}
\hline Indicator & Loading & Indicator & Loading \\
\hline $\mathrm{x} 1.1$ & 0.772 & $\mathrm{x} 2.7$ & 0.657 \\
\hline $\mathrm{x} 1.2$ & 0.802 & $\mathrm{x} 2.8$ & 0.843 \\
\hline $\mathrm{x} 1.3$ & 0.757 & $\mathrm{x} 2.9$ & 0.873 \\
\hline $\mathrm{x} 1.4$ & 0.964 & $\mathrm{x} 3.1$ & 0.863 \\
\hline $\mathrm{x} 1.5$ & 0.958 & $\mathrm{x} 3.2$ & 0.867 \\
\hline $\mathrm{x} 2.1$ & 0.700 & $\mathrm{x} 4.1$ & 0.906 \\
\hline $\mathrm{x} 2.2$ & 0.757 & $\mathrm{x} 4.2$ & 0.885 \\
\hline $\mathrm{x} 2.3$ & 0.517 & $\mathrm{y} 1$ & 0.781 \\
\hline $\mathrm{x} 2.4$ & 0.760 & $\mathrm{y} 2$ & 0.830 \\
\hline $\mathrm{x} 2.5$ & 0.629 & $\mathrm{y} 3$ & 0.817 \\
\hline $\mathrm{x} 2.6$ & 0.686 & & \\
\hline
\end{tabular}

Sumber : Output SmartPLS diolah, 2017

Suatu indikator dikatakan memenuhi convergent validity, jika mempunyai nilai loading di atas 0.500 (Ghozali, 2006, p. 25). Berdasarkan hasil yang diperoleh dari pengolahan data, semua indikator pada pengaruh variabel kualitas sistem, kualitas informasi, penggunaan informasi, kepuasan pemakai dan kepatuhan pelaporan memiliki outer loading yang lebih besar dari 0.500 , sehingga tidak ada indikator yang perlu dieliminasi dari model dan dapat dikatakan bahwa semua indikator yang digunakan mempunyai baik dalam mengukur variabel. 
b) Discriminant Validity

Tabel 8. Nilai Cross Loading

\begin{tabular}{|c|c|c|c|c|c|}
\hline & $\begin{array}{c}\text { Kepatuhan } \\
\text { Pelaporan }\end{array}$ & $\begin{array}{c}\text { Kepuasan } \\
\text { Pemakai }\end{array}$ & $\begin{array}{c}\text { Kualitas } \\
\text { Informasi }\end{array}$ & $\begin{array}{c}\text { Kualitas } \\
\text { Sistem }\end{array}$ & $\begin{array}{c}\text { Penggunaan } \\
\text { Informasi }\end{array}$ \\
\hline $\mathbf{x 1 . 1}$ & 0,698814 & 0,663035 & 0,808256 & 0,772160 & 0,723818 \\
\hline $\mathbf{x 1 . 2}$ & 0,634644 & 0,575653 & 0,726643 & 0,802067 & 0,563353 \\
\hline $\mathbf{x 1 . 3}$ & 0,628263 & 0,53903 & 0,687296 & 0,757308 & 0,554475 \\
\hline $\mathbf{x 1 . 4}$ & 0,736632 & 0,727779 & 0,864166 & 0,964439 & 0,727711 \\
\hline $\mathbf{x 1 . 5}$ & 0,780203 & 0,750588 & 0,905487 & 0,958096 & 0,72997 \\
\hline $\mathbf{2 . 1}$ & 0,611224 & 0,612781 & 0,700379 & 0,779916 & 0,620739 \\
\hline $\mathbf{2 . 2}$ & 0,658396 & 0,571365 & 0,757445 & 0,757163 & 0,570484 \\
\hline $\mathbf{2 . 3}$ & 0,475272 & 0,364435 & 0,516805 & 0,390292 & 0,38548 \\
\hline $\mathbf{x 2 . 4}$ & 0,695579 & 0,591019 & 0,759829 & 0,718366 & 0,618386 \\
\hline $\mathbf{x 2 . 5}$ & 0,605396 & 0,432387 & 0,62896 & 0,510062 & 0,523544 \\
\hline $\mathbf{x 2 . 6}$ & 0,538592 & 0,56666 & 0,685619 & 0,65511 & 0,556814 \\
\hline $\mathbf{x 2 . 7}$ & 0,522343 & 0,458356 & 0,657463 & 0,56718 & 0,40605 \\
\hline $\mathbf{x 2 . 8}$ & 0,660242 & 0,682486 & 0,84342 & 0,825561 & 0,521674 \\
\hline $\mathbf{x 2 . 9}$ & 0,687669 & 0,729173 & 0,872934 & 0,7964 & 0,609163 \\
\hline $\mathbf{x 3 . 1}$ & 0,591124 & 0,592694 & 0,652096 & 0,693101 & 0,862568 \\
\hline $\mathbf{x 3 . 2}$ & 0,59983 & 0,545964 & 0,64372 & 0,65097 & 0,866835 \\
\hline $\mathbf{x 4 . 1}$ & 0,385501 & 0,905582 & 0,709475 & 0,678872 & 0,583829 \\
\hline $\mathbf{x 4 . 2}$ & 0,35167 & 0,885323 & 0,692479 & 0,697255 & 0,596124 \\
\hline $\mathbf{y 1}$ & 0,781485 & 0,346845 & 0,701951 & 0,68418 & 0,56513 \\
\hline $\mathbf{y 2}$ & 0,829596 & 0,304069 & 0,681472 & 0,645912 & 0,51345 \\
\hline $\mathbf{y 3}$ & 0,817199 & 0,350209 & 0,677337 & 0,65329 & 0,594167 \\
\hline Sumb & $0,15 u+5 m a r t$ & & & \\
\hline
\end{tabular}

Sumber: Output SmartPLS diolah, 2017

Berdasarkan Tabel di atas diketahui bahwa indikator-indikator dari masing-masing variabel memiliki nilai cross loading terbesar pada variabel yang diukur. Dengan demikian bisa dikatakan indikator-indikator yang digunakan dalam penelitian ini telah memiliki discriminat validity yang baik dalam menyusun variabelnya masing-masing.

c) Composite Reliability

Tabel 9. Nilai Composite Reliability

\begin{tabular}{|l|c|}
\hline \multicolumn{1}{|c|}{ Variabel } & $\begin{array}{c}\text { Composite } \\
\text { Reliability }\end{array}$ \\
\hline Kepatuhan Pelaporan & 0.850899 \\
\hline Kepuasan Pemakai & 0.890071 \\
\hline Kualitas Informasi & 0.905207 \\
\hline Kualitas Sistem & 0.931115 \\
\hline Penggunaan Informasi & 0.855647 \\
\hline
\end{tabular}

Sumber : Output SmartPLS diolah, 2017 
Berdasarkan tabel di atas, hasil dari output PLS diketahui nilai composite reliability untuk variabel kepatuhan pelaporan sebesar 0.850899 , variabel kepuasan pemakai sebesar 0.890071, variabel kualitas informasi sebesar 0.905207, variabel kualitas sistem sebesar 0.931115 dan variabel penggunaan informasi sebesar 0.855647. Sehingga composite reliability dalam elemen penelitian ini adalah baik, karena nilainya di atas 0,70.

\section{Gambar 1. Hasil PLS Algorithm}

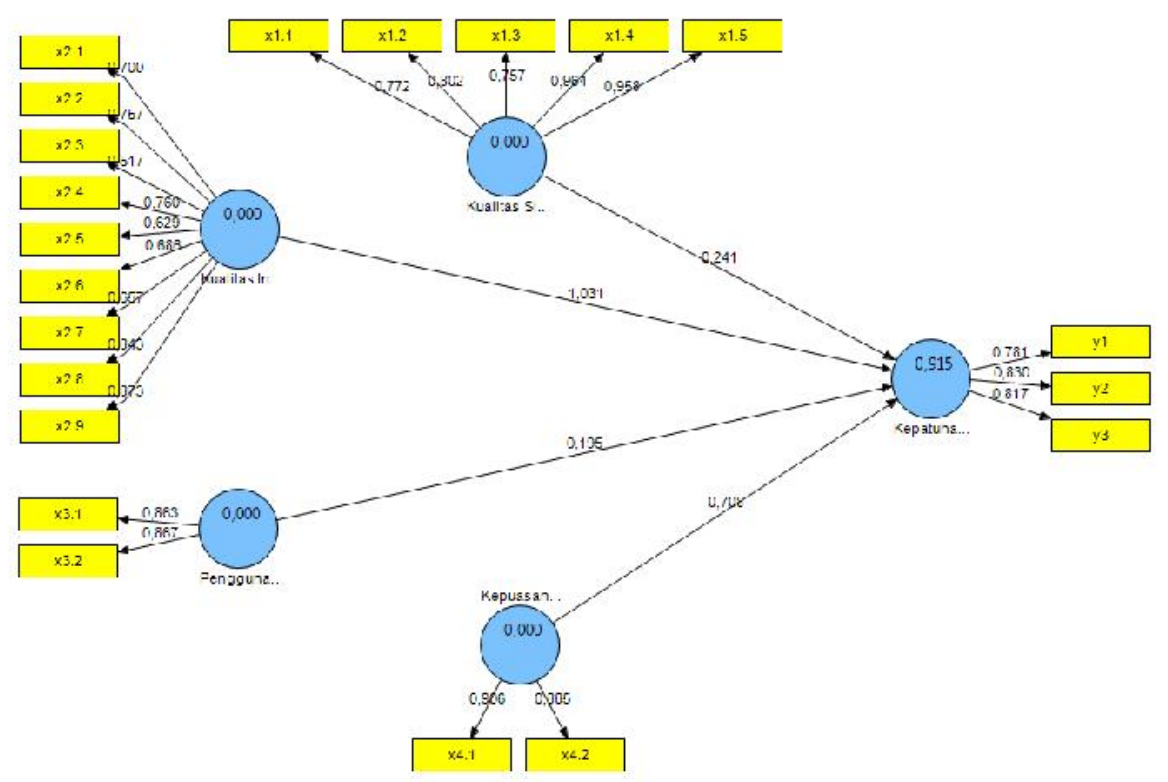

\section{Inner Model}

a) Koefisien Determinasi $\mathrm{R}^{2}$ (R-Square)

Goodness of fit pada PLS dapat diketahui dari koefisien determinasi (Rsquare $\left(\mathrm{R}^{2}\right.$ ). Berdasarkan hasil analisis, pada bagian hasil R-Square, dapat diketahui nilai $\mathrm{R}^{2}$ adalah sebesar 0.914651 atau $91.5 \%$, artinya model dapat menjelaskan data sebesar $91.5 \%$. 
b) Koefisien T-Statistik

Tabel 10. Kausalitas antar Variabel

\begin{tabular}{|c|c|c|c|c|c|}
\hline Kausalitas & $\begin{array}{c}\text { Original } \\
\text { Sample } \\
\text { (0) }\end{array}$ & $\begin{array}{l}\text { Sample } \\
\text { Mean } \\
\text { (M) }\end{array}$ & $\begin{array}{c}\text { Standard } \\
\text { Deviatio } \\
n \\
\text { (STDEV) }\end{array}$ & $\begin{array}{l}\text { Standard } \\
\text { Error } \\
\text { (STERR) }\end{array}$ & $\begin{array}{c}\text { T Statistics } \\
\text { (| O/ STERR } \\
\text { |) }\end{array}$ \\
\hline $\begin{array}{c}\text { Kepuasan } \\
\text { Pemakai -> } \\
\text { Kepatuhan } \\
\text { Pelaporan }\end{array}$ & 0,70818 & 0,69672 & 0,082834 & 0,082834 & 8,549364 \\
\hline $\begin{array}{c}\text { Kualitas } \\
\text { I nformasi - } \\
\text { > } \\
\text { Kepatuhan } \\
\text { Pelaporan }\end{array}$ & 1,031141 & 1,028736 & 0,094888 & 0,094888 & 10,86693 \\
\hline $\begin{array}{c}\text { Kualitas } \\
\text { Sistem -> } \\
\text { Kepatuhan } \\
\text { Pelaporan }\end{array}$ & 0,240682 & 0,23691 & 0,103613 & 0,103613 & 2,322898 \\
\hline $\begin{array}{c}\text { Penggunaa } \\
\text { n I nformasi } \\
\text {-> } \\
\text { Kepatuhan } \\
\text { Pelaporan }\end{array}$ & 0,195224 & 0,196868 & 0,050369 & 0,050369 & 3,875895 \\
\hline
\end{tabular}

Sumber: Output SmartPLS diolah, 2017

Berdasarkan tabel kausalitas antar variabel di atas maka diketahui bahwa semua variabel eksogen mempunyai pengaruh yang signifikan terhadap kepatuhan pelaporan dilihat dari nilai t-statistik yang lebih besar dari 2 yaitu varibel kualitas sistem terhadap kepatuhan pelaporan sebesar 2.322898, kualitas informasi terhadap kepatuhan pelaporan sebesar 10.86693, penggunaan informasi terhadap kepatuhan pelaporan sebesar 3.875895, dan kepuasan pemakai terhadap kepatuhan pelaporan sebesar 8.549364 . 


\section{Gambar 2. Model Output Bootstraping PLS}

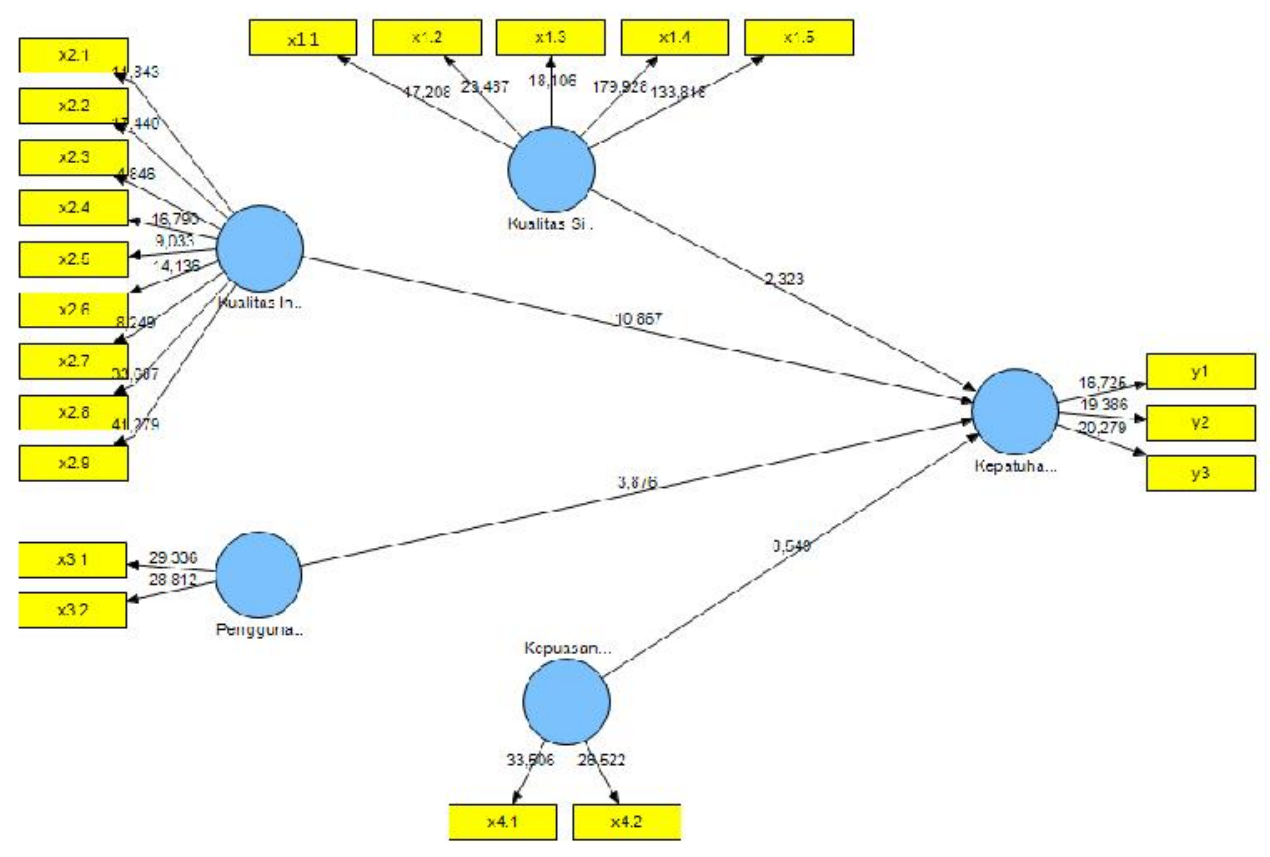

\section{KESIMPULAN}

Berdasarkan analisis data dengan menggunakan SPSS dan smartPLS maka diperoleh kesimpulan antara lain sebagai berikut

1. Implementasi sistem $e$-filing dalam sistem pelaporan Surat Pemberitahuan Tahunan dari persepsi wajib pajak berdasarkan dimensi kualitas sistem wajib pajak merasakan kemudahaan penggunaan sistem $e$-filing untuk membantu mereka dalam melaporkan SPT nya. Dalam dimensi kualitas informasi isi atau komponen dalam sistem E-filing memberikan informasi yang memadai sehingga wajib pajak mampu mendapatkan informasi yang diinginkan. Pada dimensi penggunaan informasi sistem $e$-filing tidak dipengaruhi berapa banyak pengguna yang mengakses saat itu namun frekuensi responden yang menyatakan setuju sama besar dengan netral sehingga diasumsikan banyaknya pemakai saat itu juga dipengaruhi faktor lainnya. Dimesi kepuasan pemakai lebih difokuskan lagi pada kepuasan informasi yang diberikan dengan sistem $e$-filing banyak wajib pajak yang bersikap netral, tapi jika kepuasan secara menyeluruh banyak wajib pajak yang merasa puas.

2. Karakteristik kepatuhan pelaporan Surat Pemberitahuan Tahunan dengan menggunakan sistem e-filing mampu membantu wajib pajak terhindar dari keterlambatan pelaporan dan denda keterlambatan pelaporan SPT 
3. Terdapat pengaruh yang signifikan antara $e$-filing dengan kepatuhan pelaporan Surat Pemberitahuan tahunan.

\section{DAFTAR PUSTAKA}

Agustiningsih, Wulandari. Isroah. 2016. Pengaruh penerapan e-filing, tingkat pemahaman perpajakan dan kesadaran wajib pajak terhadap kepatuhan wajib pajak di KPP Pratama Yogyakarta. Jurnal Nominal. Volume V No. 2 Tahun 2016. Prodi Akuntansi. Universitas Negeri Yogyakarta

Dewi, A.A, Ratih, Khomalyana. 2009. Analisis Faktor-faktor yang mempengaruhi Penerimaan Wajib Pajak terhadap Penggunaan e-filing. Skripsi. Fakultas Ekonomi. Universitas Diponegoro. Tembalang.

Jogiyanto HM. (2007). Sistem Teknologi Informasi, Andi, Yogyakarta.

Keputusan Direktur Jendral Pajak nomor KEP-88 / PJ/ 2004 Tgl 14 Mei 2004

Keputusan Direktur Jendral Pajak nomor KEP-05 / PJ/ 2005 Tgl. 12 Januari 2005 Tentang tata cara penyampaian surat pemberitahuan secara elektronik (e-filing)

Peraturan Dirjen Pajak PER 1/PJ/2014. Tata cara penyampaian surat pemberitahuan tahunan bagi wajib pajak orang pribadi yang menggunakan formulir 1770s atau 1770ss secara e-filing melalui website direktorat jenderal pajak (www.pajak.go.id)

Marzuki.2000. Metodelogi Riset. Yogyakarta: Prasetia Widia Pratama

Peraturan Menteri Keuangan. No.192 / PMK.03/2007. Tentang Kategori kepatuhan wajib pajak

Widilestariningtyas, Utami. 2014. Penerapan e-filing dan kesadaran wajib pajak terhadap kepatuhan formal (Survey pada WP OP Pekerjaan Bebas di KPP Pratama Bandung Karees). Universitas Komputer Indonesia. http://elib.unikom.ac.id/files/disk1/669/jbptunikompp-gdl-gartinawul-33443-1unikom_g-l.pdf

Wiyono, Andrianto Sugiarto.2008. Evaluasi Perilaku Penerimaan Wajib Pajak Terhadap Penggunaan E-filing sebagai sarana pelaporan pajak secara online dan realtime. Jurnal Riset Akuntansi ndonesia. Vol 11. No.2. Hal. 117-132. 